ing the importance of the data in this type of survey being primarily recorded by general practitioners.

There is an impression among those dealing with a large number of "cot death" cases that these infants tend to be significantly overweight for their age (J. L. Emery, personal communication, 1970). One child in our series suffered a cot death during the period of the trial, and this infant was in the group of children who were over the 90th percentile for age; necropsy gave the cause of death as resulting from acute bronchiolitis. This may well be a chance finding in a relatively large series of children, but it points the need for further investigation in this field.

If it be assumed that the case is proved, and that obese infants do have a greater liability to respiratory infection than those of normal weight, the question arises why this should be the case. Two possibilities emerge as indications for further investigation. Firstly, that obesity leads to underventilation of the lungs, with possible impairment of coughing and clearing of secretions from the respiratory tree, leading to a tendency for minor respiratory infections to become more serious and prolonged. The second possible mechanism by which obesity might predispose to an increased incidence of respiratory infection could be due to a defect in the immune defences of the body, associated either directly with the obesity or indirectly with the early introduction of artificial feeding. The early abandonment of breast-feeding may also play a part in the reduction of the immune response at this $\frac{0}{-}$ age. Further work on both of these possibilities would be valu- 3 able and interesting, and we hope that our clinical survey will $\stackrel{\circ}{\circ}$ stimulate more detailed biochemical and respiratory function $\subseteq$ studies in this field.

We are grateful to local general practitioners for their help and $\stackrel{?}{\frac{9}{9}}$ co-operation, without which this paper could not have been written; to Dr. W. J. McQuillan for advice and encouragement, and to the $\overline{\bar{\omega}}$ health visitors in his department for recording weights and other $\vec{\nabla}$ details of babies and collection of data cards from general practition- $\propto$ ers; to the department of statistics, University of Birmingham, for $\%$ advice on the statistical aspects of the trial; and to Dr. Brian $\vec{O}$ Williams, who also gave helpful criticism and advice.

\section{References}

British Medical fournal, 1970, 2, 64.

Hutchinson-Smith, B. (1970). Medical Officer, 123, 257.

Tanner, J. M., Whitehouse, R. H., and Takaishi, M., (1966). Archives of $\mathrm{G}$ Disease in Childhood, 41, 613.

\title{
Infectious Complications in Bone Marrow Transplant Patients
}

\author{
C. O. SOlbERG, H. J. MEUWISSEN, R. N. NEEDHAM, R. A. GOOD, J. M. MATSEN
}

British Medical fournal, 1971, 1, 18-23

\section{Summary}

In 11 patients receiving transplants of allogeneic bone marrow, the graft was successful in six. Nine patients developed infections, and six died-five of septicaemia and one of Pneumocystis carinii pneumonia. Fifty individual infections occurred. Predisposing factors included severe underlying diseases, long-term exposure to resistant hospital organisms, heavy immunosuppressive therapy, and graft-versus-host disease. Gram-negative bacilli and Candida albicans were the most common causative organisms. In every instance of septicaemia identical organisms were isolated from blood cultures and simultaneously obtained stool cultures. Infection with exogenous organisms often occurred in patients occupying conventional isolation rooms. Isolation of one patient for 45 days in a laminar air flow room prevented infection with exogenous organisms.

\section{Introduction}

Infection remains a major problem in all types of internal organ transplantation (Rifkind et al., 1964; Kelly et al., 1967;

University of Minnesota Medical Center, Minneapolis, Minnesota 5545 C. O. SOLBERG, M.D., Associate Professor of Medicine. (Present address: School of Medicine, Medical Department B, University of! Bergen, Bergen, Norway)

H. J. MEUWISSEN, M.D., Lecturer

R. N. NEEDHAM, B.S., Research Fellow

R. A. GOOD, M.D., PH.D., Regent's Professor of Paediatrics and Micro-

J. M. MATSEN, M.D., Assistant Professor of Paediatrics and Laboratory Medicine
Fulginiti et al., 1968; Montgomery et al., 1969). Bone marrowळ transplantation is still in its early stages (Pegg, 1966; Mathé $\vec{F}$ et al., 1967), and studies of associated infections are limited 3 (Mathé et al., 1965). It is apparent, however, that candidates? for bone marrow transplantation are particularly susceptible to infection owing to the nature of their underlying disease processes (Mathé et al., 1967; Bergsma and Good, 1968), the heavy immunosuppressive therapy often required to obtain a take of the graft, and the subsequent occurrence of graft- 3 . versus-host disease (Blaese et al., 1964; Mathé et al., 1965).

The present study reports the infectious complications in bone marrow transplant patients at the University of Minnesota Medical Center from 1968 to 1970. Results of extensive microbiological monitoring of patients establishedos the origin of several infections and provided information for improved prophylaxis and therapy in future bone marrow transplantation.

\section{Patients and Methods}

Eleven patients received transplants of allogeneic* bone mar $\stackrel{\mathbb{\infty}}{?}$ row. All suffered from a variety of serious life-threatening 0 diseases. Details of the patients' diagnoses, age, sex, and bone marrow transplantation are presented in Table I. The methods of histocompatibility matching and the technique of bone marrow transplantation have already been described (Meuwissen et al., 1969).

Demonstrable cell-mediated immune functions were̊ completely absent in Cases 1-4, deficient in Cases 5-7, and unimpaired in Cases $8-11$. Case 4 received small doses of methotrexate to facilitate the take of the bone marrow while Cases 1-3 received no immunosuppressive therapy. In addi* Allogeneic: of same species but not of identical genetic constitution-for
example, father and son. 
TABLE I-Bone Marrow Transplant Patients

\begin{tabular}{|c|c|c|c|c|c|}
\hline $\begin{array}{l}\text { Case } \\
\text { No. }\end{array}$ & Age and Sex & Disease & Bone Marrow Donor & Immunosuppressive Therapy & Outcome \\
\hline 1 & 5 months. & Sex-linked lymphopenic & Sister, MLC compatible, CTA & None & Immunological reconstitution \\
\hline 2 & $\begin{array}{l}7 \text { months. } \\
\text { Female }\end{array}$ & $\begin{array}{l}\text { nypogammagiooulinnaemia } \\
\text { hypogammaglobulinaemia }\end{array}$ & Sister, HL-A identical & None & $\begin{array}{l}\text { Immunological reconstitution; } \\
\text { chronic GVHD }\end{array}$ \\
\hline 3 & $\begin{array}{l}13 \text { months. } \\
\text { Male }\end{array}$ & $\begin{array}{l}\text { Sex-linked lymphopenic } \\
\text { hypogammaglobulinaemia }\end{array}$ & Sister, HL-A identical & None & $\begin{array}{l}\text { Beginning immunological } \\
\text { reconstitution. Died of infection } \\
27 \text { days after TP }\end{array}$ \\
\hline 4 & $\begin{array}{l}10 \text { months. } \\
\text { Male }\end{array}$ & $\begin{array}{l}\text { Sex-linked lymphopenic } \\
\text { hypogammaglobulinaemia }\end{array}$ & $\begin{array}{l}\text { Father, MLC and CTA } \\
\text { incompatible }\end{array}$ & $\begin{array}{l}\text { Antihuman lymphocyte serum. } \\
\text { Methotrexate } 0.5 \mathrm{mg} / / \mathrm{kg} \text { with 3-6 } \\
\text { day intervals after TP }\end{array}$ & $\begin{array}{l}\text { Beginning immunological } \\
\text { reconstitution. Died of infection } \\
42 \text { days after TP }\end{array}$ \\
\hline 5 & $\begin{array}{l}15 \text { years. } \\
\text { Male }\end{array}$ & Hodgkin's disease, stage IV B & Brother, HL-A identical & $\begin{array}{l}\text { Cyclophosphamide } 50 \mathrm{mg} \text {.//kg } \\
\text { daily for } 2 \text { days before TP }\end{array}$ & $\begin{array}{l}\text { Beginning immunological } \\
\text { reconstitution. Died of infection }\end{array}$ \\
\hline 6 & $\begin{array}{l}15 \text { years. } \\
\text { Male }\end{array}$ & Hodgkin's disease, stage IV B & Brother, HL-A identical & $\begin{array}{l}\text { Long-term chemotherapy } \\
\text { discontinued } 2 \text { weeks before TP }\end{array}$ & $\begin{array}{l}\text { No immunological } \\
\text { reconstitution. Died of Hodgkin's } \\
\text { disease of stomach }\end{array}$ \\
\hline 7 & $\begin{array}{l}7 \text { years. } \\
\text { Female }\end{array}$ & $\begin{array}{l}\text { Chronic mucocutaneous } \\
\text { candidiasis }\end{array}$ & $\begin{array}{l}\text { Sister, MLC and CTA } \\
\text { incompatible }\end{array}$ & & $\begin{array}{l}\text { Improvement of candidiasis; } \\
\text { chronic GVHD }\end{array}$ \\
\hline 8 & $\begin{array}{l}8 \text { years. } \\
\text { Male }\end{array}$ & $\begin{array}{l}\text { Non-lymphopenic } \\
\text { hypogammaglobulinaemia } \\
\text { (Bruton's type) }\end{array}$ & Sister, HL-A identical & None & $\begin{array}{l}\text { No immunological } \\
\text { reconstitution }\end{array}$ \\
\hline 9 & $\begin{array}{l}9 \text { years. } \\
\text { Female }\end{array}$ & Idiopathic aplastic anaemia & Brother, HL-A identical & $\begin{array}{l}\text { Before 1st TP: antilymphocyte } \\
\text { serum, prednisone and } \\
\text { azathioprine. 2nd TP: } \\
\text { cyclophosphamide } 60 \mathrm{mg} . / \mathrm{kg} \\
\text { daily for } 3 \text { days before TP }\end{array}$ & Died of infection 16 days after TP \\
\hline 10 & $\begin{array}{l}21 \text { years. } \\
\text { Female }\end{array}$ & $\begin{array}{l}\text { Aplastic anaemia } \\
\text { (drug-induced?) }\end{array}$ & Brother, HL-A identical & $\begin{array}{l}\text { Long-term prednisone. } \\
\text { Cyclophosphamide } 75 \mathrm{mg} . / \mathrm{kg}\end{array}$ & Died of infection 3 days after TP \\
\hline 11 & $\begin{array}{l}25 \text { years. } \\
\text { Female }\end{array}$ & Acute lymphoblastic leukaemia & Sister, MLC compatible? & $\begin{array}{l}\text { Long-term prednisone. } \\
\text { Cyclophosphamide } 37.5 \mathrm{mg} . / \mathrm{kg} \\
\text { daily for } 2 \text { days before TP }\end{array}$ & $\begin{array}{l}\text { Recovery of bone marrow and } \\
\text { transient remission of leukaemia. } \\
\text { Died of infection } 122 \text { days after TP }\end{array}$ \\
\hline
\end{tabular}

MLC $=$ Mixed leu cocyte culture. CTA $=$ Cytotoxic assay. $T P=$ Transplantation. GVHD $=$ Graft-versus-host disease.

tion to other drugs high doses of cyclophosphamide were given to Case 5 and to Cases 9-11. Seven patients received HLA identical sibling bone marrow. Graft-versus-host disease occurred in six patients (Table I).

The principal markers for the presence and function of donor cells in the recipient were as follows: (1) sex chromosome markers, (2) red blood cell antigenic markers, (3) gammaglobulin allotype markers (kindly performed by Dr. Arthur Steinberg), (4) functional criteria such as increased gammaglobulin production in hypogammaglobulinaemic patients or the appearance of lymphocytes and in-vitro lymphocyte function in previously lymphopenic unresponsive patients, and (5) transfer of delayed hypersensitivity from donor to recipient.

\section{Immunological Reconstitution}

In Cases 1 and 2 immunological reconstitution was documented by persistent production of immunoglobulins, antibodies, and the in-vitro lymphocyte response to phytohaemagglutinin and allogeneic cells. In Case 1 (a male) peripheral blood lymphocytes, dividing under the influence of phytohaemagglutinin, were of female karyotype, whereas spontaneously dividing bone marrow cells showed a mixture of male and female karyotypes. Eight weeks after transplantation this patient developed immunologically induced pancytopenia attributed to a reaction of the grafted lymphoid cells against host constituents. One month later treatment of the pancytopenia with a second marrow transplant was as successful in restoring the red-cell, platelet, and granulocyte populations as the first had been in establishing the lymphocyte and plasma cell lines (Meuwissen et al., 1969). Cases 1 and 2 were still in good clinical condition and immunologically reconstituted 23 and 16 months after transplantation, respectively.

In Cases 3 and 4 the onset of immunological reconstitution was shown by a rise in phytohaemagglutinin-stimulated blastoid cells in peripheral blood lymphocyte cultures, and by a positive response to a challenging dose of dinitrofluorobenzene, $1 / 1,000$, and to intradermal IgE. In Case 3 necropsy also showed proliferating bone marrow in the subcutaneous fat around the site of the peritoneal catheter used for bone marrow transplantation, and in Case 4 donor type red blood cells occurred in the peripheral blood one week after transplantation, while these cells had previously been absent.
In Case 5 necropsy showed infiltration of the lymph nodes and the spleen by numerous plasma cells and large pale blastoid cells characteristic of graft-versus-host disease. Lesions typical of this disease were also present in the skin. Case 11 had a second relapse of acute lymphoblastic leukaemia and showed no response to prolonged treatment with various antileukaemic drugs. Complete recovery of the marrow occurred after bone marrow transplantation. Three months later a third relapse occurred and the patient died. In the absence of markers, donor type cells could not be found in the blood. In the remaining patients no evidence of take of bone marrow was found.

\section{Bacteriological Tests}

Microbiological sampling and culturing methods and biochemical and serological organism identification techniques have been described (Solberg et al., 1970). Sensitivity determinations were done with either the twofold tube dilution method (using Mueller-Hinton broth (BBL) and an inoculum of $10^{5}-10^{6}$ organisms per $\mathrm{ml}$ ) or the single high-potency disc technique (Bauer et al., 1966). Identity of bacterial strains was documented by antibacterial spectra in addition to the biochemical and serological techniques indicated above.

A diagnosis of septicaemia was based on positive blood cultures together with other evidence of septicaemia-that is, a primary site of infection, spiking fever, shock, and/or gastrointestinal symptoms. The presence of pulmonary infection was judged by typical clinical and roentgenological findings together with a predominant growth of micro-organisms in repeated deep cough sputum cultures or deep tracheal aspiration cultures. Urinary tract infection was diagnosed when urine catheter or midstream specimens contained $10^{5}$ or more organisms per $\mathrm{ml}$.

\section{Results}

\section{INCIDENCE OF INFECTIONS}

A total of 50 individual infections occurred in 9 of the 11 transplant patients. Cases 6 and 8 did not develop infection related to bone marrow transplantation. Each failed to have a definite take of the bone marrow and no evidence of graftversus-host disease was observed. In the remaining patients, 
nine infections occurred during the three weeks before transplantation; eight were cured and one infection was carried over to the post-transplantation period. After transplantation 41 additional infections developed.

\section{INFECTING ORGANISMS}

Twenty-eight infections in eight patients were caused by Gram-negative bacilli (Table II). Candida albicans accounted for nine infections in four patients, Staphylococcus aureus for five infections in four patients, Haemophilus influenzae for two infections in two patients, and, finally, Bacillus sp., Bacteroides sp., Clostridium perfringens, enterococcus, and Pneumocystis carinii accounted for or were involved in 12 infections in five patients.

\section{TYPE OF INFECTION}

Septicaemia occurred eight times in six patients; two patients had two episodes, the organisms isolated during the two episodes being different (Chart, Table II). Seven of the eight septic episodes occurred after transplanation. Enteric Gramnegative bacilli were involved six times, and $C$. albicans and Bacteroides sp. once each. Infection with multiple organisms, from two to five pathogens verified by two or three consecutive blood cultures, occurred in four instances. In all septic episodes blood cultures grew out strains also isolated from simultaneously obtained stool cultures. Septicaemia was the primary cause of death in five patients, three of these also having internal organ abscesses (Table III).

Pneumonia occurred 11 times in six patients (Chart, Table II). The principal causative organisms were Klebsiella sp., Pn. carinii, and Staph. aureus. Three infections occurred before transplantation and were eradicated. Pneumonia was the primary cause of death of one patient, and a contributing cause in another patient (Table III). Pn. carinii was the infecting organism in both patients, and in each instance the organism, most probably, was carried over from the pretransplant period.

Urinary tract infections occurred 11 times in seven patients. Gram-negative bacilli were present in 10 cases and $C$. albicans in one. Cure was achieved in eight instances. In two
TABLE III-Terminal Infectious Diseases in Six Bone Marrow Transplant Patients

\begin{tabular}{|c|c|c|c|}
\hline $\begin{array}{l}\text { Case } \\
\text { No. }\end{array}$ & $\begin{array}{l}\text { Survival } \\
\text { (Days) }\end{array}$ & Infectious Disease & Aetiology \\
\hline 3 & 27 & Pneumonia & Pn. carinii \\
\hline 4 & 42\{ & $\begin{array}{l}\text { Septicaemia } \\
\text { Pneumonia }\end{array}$ & $\begin{array}{l}\text { E. coli, Ps. aeruginosa } \\
\text { Pn. carinii }\end{array}$ \\
\hline 5 & 27\{ & $\begin{array}{l}\text { Septicaemia } \\
\text { Lung and spleen abscesses }\end{array}$ & $\begin{array}{l}\text { Ps. aeruginosa } \\
\text { E. coli, Pr. mirabilis }\end{array}$ \\
\hline 9 & 16 & $\begin{array}{l}\text { Septicaemia } \\
\text { Multiple metastatic abscesses }\end{array}$ & $\begin{array}{l}\text { Bacillus sp., Cl. perfringens, } \\
\text { enterococcus, } \\
\text { Klebsiella sp. } \\
\text { coli, } \\
\text { Bacillus sp., Cl. perfringens, } \\
\text { enterococcus, } \\
\text { Klebsiella sp. }\end{array}$ \\
\hline 10 & 3\{ & $\begin{array}{l}\text { Septicaemia } \\
\text { Urinary tract infection }\end{array}$ & $\begin{array}{l}\text { E. coli } \\
\text { E. coli }\end{array}$ \\
\hline 11 & 122\{ & $\begin{array}{l}\text { Septicaemia } \\
\text { Multiple metastatic abscesses }\end{array}$ & $\begin{array}{l}\text { C. Albicans } \\
\text { C. Albicans }\end{array}$ \\
\hline
\end{tabular}

patients who died of septicaemia the organisms were never eradicated from the urine. In these patients identical organisms were isolated from urine and blood cultures.

Cases 5, 9, and 11 had multiple metastatic abscesses in the brain, gastrointestinal wall, kidneys, liver, lungs, and/or spleen in addition to septicaemia. Identical organisms were isolated from the abscesses and blood cultures. Case 7 developed lung abscesses after pneumonia with enterococci.

Seven patients had miscellaneous infections-that is, $N$ mucocutaneous candidiasis, otitis media, draining pustules, and wounds. Case 7 had suffered from mucocutaneous candidiasis for several years and improved significantly after $\underset{\gtrless}{\gtrless}$ transplantation. The other patients were successfully treated $\vec{\theta}$ with antibiotics.

RELATION TO IMMUNOSUPPRESSIVE THERAPY AND GRAFT-VERSUSHOST DISEASE

Owing in part to immunosuppressive therapy before $\stackrel{\Phi}{\circ}$ transplantation, Cases 5 and $9-11$ had granulocyte counts less $\overrightarrow{\vec{P}}$ than $100 / \mathrm{mm}^{3}$ for several days after transplantation. Each developed septicaemia, and three patients (Cases 5, 9, and 10) with Hodgkin's disease and aplastic anaemia died 27, 16 and 7 3 days after transplantation, respectively. Necropsy of these three patients showed diffuse necrosis and patchy ulcerations of the gastrointestinal mucosa.

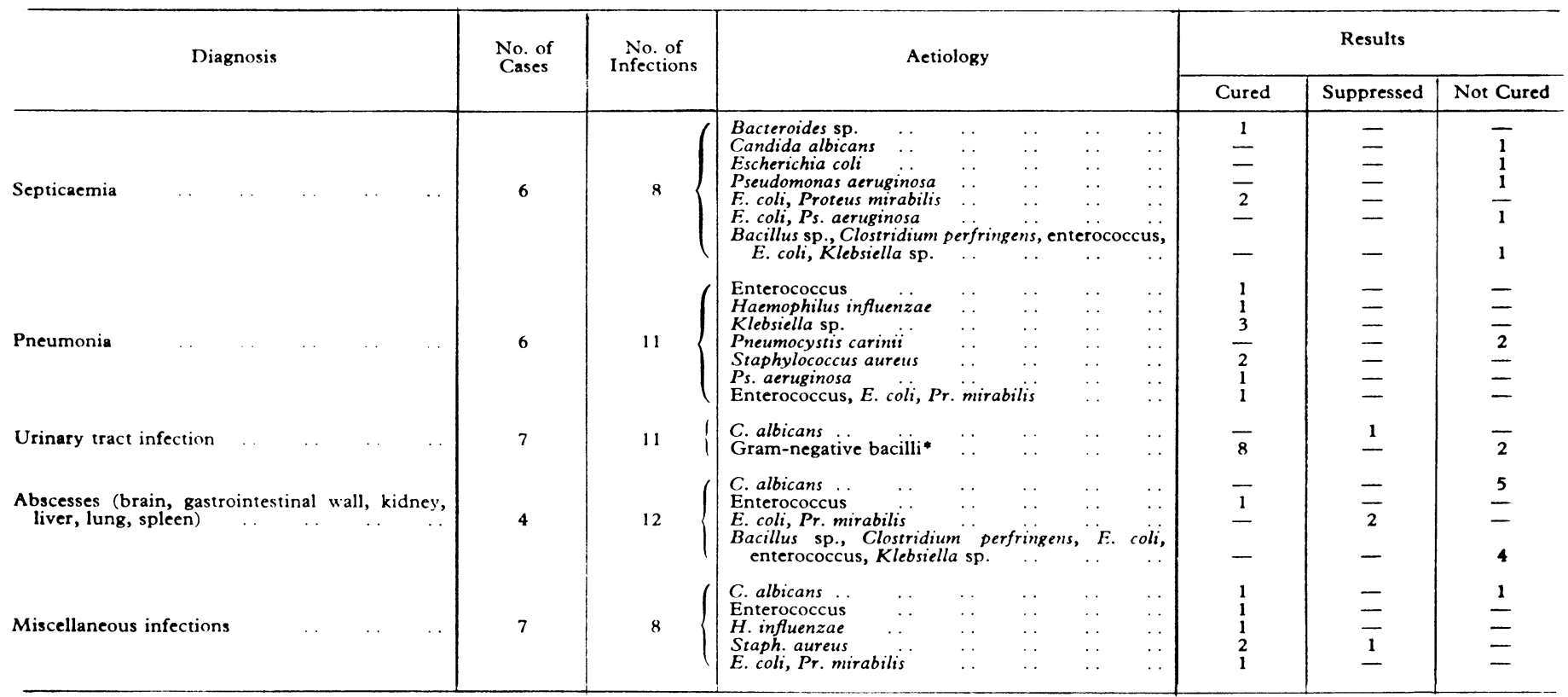


Cases $1-5$ and 7 developed graft-versus-host diseasc from one to five weeks after bone marrow transplantation. In these patients 21 infections occurred after transplantation-three in the period between transplantation and the onset of graftversus-host disease and 18 during the first five weeks of graft-versus-host disease (see Chart). laminar air flow room. Case 4 occupied the laminar air flow room for 45 days. This patient maintained his own endogenous bacterial flora during his entire stay in the laminar air flow room, and no contamination or infection occurred with organisms from the environment or from the personnel entering the room. The terminal septicaemia was

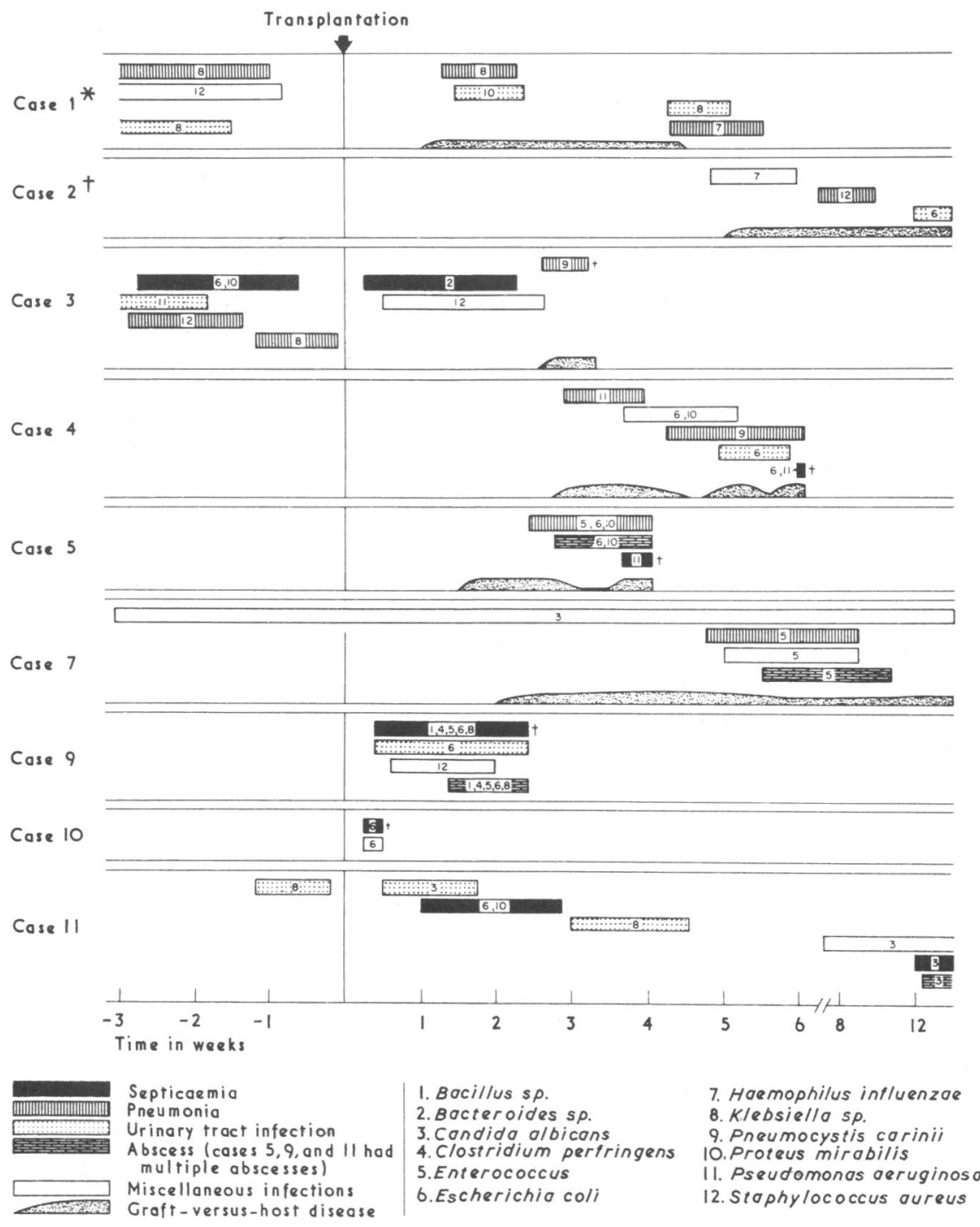

Infections in relation to bone marrow transplantation and graft-versus-host disease. ${ }^{*}$ Later, the patient received one more bone marrow transplant without evidence of graftversus-host disease and infectious complications tPreviously the patient TPreviously the patient had received a hone marrow transplant with littlc or no evidence of immunological reconstitution, no graft-versus-host disease and no infectious complications.

Cases 1-4 with absence of demonstrable cell-mediated immune functions all developed graft-versus-host disease. Cases 1-3 received $\mathrm{HL}-\mathrm{A}$ identical marrow, and the graftversus-host disease symptoms were less severe than in Case 4, who received HL-A non-identical paternal marrow. Two patients (Cases 1 and 2) recovered from their graft-versushost disease and did not develop life-threatening symptoms. One (Case 3) developed severe $P n$. carinii pneumonia and died 27 days after transplantation, and one (Case 4) died of massive septicaemia, pneumonia, and multiple gastrointestinal ulcerations, probably caused by his severe graft-versus-host disease.

\section{ORIGIN OF INFECTION}

In cases $1,3,4,5$, and 9 bacteriological samples from the nose, throat, axillae, groin, perineum, urine, and stool were obtained regularly at intervals of two to four days. On admission Case 4 was kept in a laminar air flow room under strict isolation procedures (Solberg et al., 1970), while the other four were isolated in non-laminar air flow hospital rooms, but under the same isolation procedures as in the caused by Klebsiella sp. and Ps. aeruginosa identical to strains repeatedly isolated from his stool.

In the other four patients colonization of the nose, throat, and gut with exogenous organisms (Ps. aeruginosa, Klebsiella, Moraxella, and/or Bacillus sp.) occurred from 5 to 29 days after admission to hospital. Initially the organisms were isolated in small numbers, but within two to seven days large numbers were usually recovered. Cases 1 and 5 developed infections with these organisms eight and five days after colonization, respectively. Case 1 developed pneumonia with a Klebsiella strain identical to that which had recently colonized his throat. Case 5 developed septicaemia with a Pseudomonas strain identical to that which had colonized his gut. Case 9 also developed septicaemia, and several blood cultures grew out five different organisms, identical to strains being isolated from simultaneously obtained stool cultures. One of these strains (Klebsiella sp.) had colonized the gut 20 weeks previously. Two patients (Cases 5 and 9) died of septicaemia. Case 3 had two episodes of septicaemia and had pneumonia three times. There was no evidence of exogenous organisms causing these infections. The first episode of septicaemia was caused by $E$. coli and $\mathrm{Pr}$. mirabilis and the second by Bacteroides sp., organisms which were repeatedly isolated in large numbers from the patient's stools. 


\section{Discussion}

Infection has been one of the most serious complications of organ transplantation. In renal transplantation infections have contributed to more than two-thirds of the deaths (Rifkind et al., 1964; Kelly et al., 1967), and in 17 recipients of liver homografts Fulginiti et al. (1968) reported that 10 of the 15 deaths were due to infectious complications. Montgomery et al. (1969) found that 10 out of 28 cardiac transplant patients died of infections complicating the surgery and subsequent immunosuppressive therapy. The principal reasons for the severe infections in solid organ transplantation include heavy immunosuppressive therapy, complicated surgical procedures, vascular post-surgery complications, and longterm exposure of debilitated patients to resistant hospital organisms.

As documented in our study, infection is also a serious complication in bone marrow transplantation. Nine of the 11 patients in our series experienced a total of 41 infections after transplantation neither received immunosuppressive therapy tions. Two who did not develop infection in relation to transplantation, neither received immunosuppressive therapy nor developed graft-versus-host disease. The principal reasons for the increased susceptibility to infection in our patients include severe underlying medical problems, long-term exposure to antibiotic-resistant hospital organisms, heavy immunosuppressive therapy, and, finally, frequent occurrence of graft-versus-host disease.

All patients reported here had severe underlying diseases, including hypogammaglobulinaemia, chronic mucocutaneous candidiasis, neoplasia, and aplastic anaemia. In all of these conditions there is a predisposition to either a specific infectious process (in mucocutaneous candidiasis) or to opportunistic infections in general. Before transplantation our patients had experienced repeated infections resulting in frequent admission to hospital with the inherent risk of exposure to antibiotic-resistant hospital organisms. Infections due to hospital-adapted strains are usually more difficult to treat, and the persistence of the organisms appears to be enhanced (McDermott, 1957).

In addition to severe underlying diseases and long-term exposure to resistant hospital organisms, immunosuppressive therapy greatly enhanced the susceptibility of our patients to infection. Six patients in the present series received cyclophosphamide, methotrexate, prednisone, azathioprine, and/or antihuman lymphocyte serum to suppress the immune response in order to obviate transplant rejection. Two patients with aplastic anaemia, one with Hodgkin's disease, and one with acute leukaemia-all with pre-existing granulocytopenia-had fewer than 100 granulocytes per $\mathrm{mm}^{3}$ for several days after administration of cyclophosphamide. The three patients with aplastic anaemia and Hodgkin's disease also developed widespread necrosis of the intestinal mucosa. Despite heroic measures, including repeated leucocyte transfusions, each of these four patients developed septicaemia with organisms present in the gut flora, and the three patients with aplastic anaemia and Hodgkin's disease died within a few days. High doses of cyclophosphamide are known to produce intravascular coagulation in all tissues in monkeys (van Bekkum et al., 1970) and haemorrhagic gastroenteritis in dogs (Epstein et al., 1969). Therefore the gut necrosis which occurred in our patients may have been related to the high doses of cyclophosphamide. The pronounced neutropenia was in all likelihood a direct result of the administration of this drug.

Finally, graft-versus-host disease is associated with a pronounced degree of immunological incompetence due to production of lymphoid atrophy and depression of bone marrow (Blaese et al., 1964; Mathé et al., 1967; van Bekkum and de Vries, 1967). Furthermore, graft-versus-host disease may cause severe damage to the intestinal mucosa, resulting in continuous seeding of enteric organisms into the blood and persistence of septicaemia despite what might appear to be adequate therapy by in-vitro testing (de Vries et al., 1961). Six of our patients developed graft-versus-host disease. In these patients 18 separate infections occurred within four to five weeks after the onset of graft-versus-host disease, and three died-one of pneumonia and two of septicaemia. The latter two patients had multiple intestinal ulcerations, and identical organisms were isolated from the blood and stool cultures.

In the eight septic episodes which occurred in our patients, blood cultures always grew out strains isolated from simultaneously obtained stool cultures, and four of the five patients who died of septicaemia had multiple intestinal ulcerations, most likely related to graft-versus-host disease and/or administration of cyclophosphamide. Therefore, in future patients intestinal decontamination with non-absorbable antibacterial and antifungal agents should be considered. Decontamination of the gut flora may prevent fatal septicaemia caused by seeding of enteric organisms into the blood Furthermore, the gastrointestinal damage which occurs after bone marrow transplantation may be less severe and healing may occur more rapidly if the load of intestinal organisms is reduced. Finally, evidence is accumulating that intestinal decontamination may reduce the severity of graft-versus-host disease (Keast, 1968; Ledney, 1969).

\section{INFECTION WITH EXOGENOUS ORGANISMS}

The principal drawback of intestinal decontamination remains the risk of superinfection with exogenous organisms resistant to the antimicrobial agents used. It should be possible, however, to minimize this risk in the future by using strict aseptic techniques, by sterilizing all food, medications, and utensils used for the patients, and by use of laminar air flow rooms (Solberg et al., 1970).

The importance of infection with exogenous organisms in these highly susceptible patients should not be overlooked. Four of our patients occupying conventional isolation rooms were the subjects of extensive bacteriological monitoring. Each was colonized with exogenous organisms 5 to 29 days after admission to hospital. Later, three of these patients developed documented infections due to those organisms, and two died. In these three patients organisms originally exogenous became part of the resident flora and greatly increased in numbers for several days to weeks before precipitating the infectious episodes. The other bone marrow transplant patients who occupied conventional isolation rooms were not the subjects of extensive bacteriological monitoring. Most probably some of the infections which occurred in these patients were also due to exogenous organisms. In contrast, one of our patients was kept in a laminar air flow room for 45 days, under strict isolation procedures. Extensive microbiological monitoring of the patient, the laminar air flow room, and the personnel entering the isolation facility showed that the patient maintained his endogenous bacterial flora during his entire stay in the room, and no colonization occurred with organisms from the environment or from any of the personnel entering the room. To prevent infection with exogenous organisms in future bone marrow transplantation. admission of the patients to laminar air flow rooms under strict isolation seems indicated, especially if intestinal decontamination is attempted.

Despite the frequent occurrence of fatal infections in bone marrow transplantation, aggressive attempts at diagnosis are of far more than academic interest since several of these infections, including those caused by fungi and $P n$. carinii, can be treated by large doses of antimicrobial agents and immune globulins (Rifkind et al., 1966). The rapid onset and fulminant course of infections in these patients, especially during periods of heavy immunosuppressive therapy or graftversus-host disease, requires close observation by skilled per- 
sonnel and early institution of therapy. Continuous monitoring of the patients' flora may often help to ensure specific therapy before results of appropriate cultures are available, as shown in our septicaemia patients who always developed infections with organisms present in the intestinal flora. To secure a specific bacteriological diagnosis, however, the value of blood cultures, endotracheal aspirations, and urine and wound cultures should be emphasized in view of the repeatedly significant findings in these samples.

In future bone marrow transplantations, admission of patients to laminar air flow rooms under strict isolation conditions, and decontamination of the intestinal flora, may be important steps in ensuring survival of the patients. Improved immunosuppressive therapy and methods to ameliorate the graft-versus-host disease, however, seem more important in preventing fatal infections.

This work was supported in part by U.S. Public Health Service Grants 1F05-TW-01494-01, 1-R01-CA11505-01, AI-08677, and HE-06314, and by grants from the National Foundation-March of Dimes, and the American Heart Association.

Requests for reprints should be addressed to Dr. John $M$. Matsen, Box 198, University of Minnesota Hospital, Minneapolis, Minnesota 55455, U.S.A.

\section{References}

Bauer, A. W., Kirby, W. M. M., Sherris, J. C., and Turck, M. (1966). American fournal of Clinical Pathology, 45, 493.

Bergsma, D., and Good, R. A. (editors)(1968). Immunologic Deficiency Diseases in Man. New York, National Foundation.

Blaese, R. M., Martinez, C., and Good, R. A. (1964). Journal of Experimental Medicine, 119, 211 .

de Vries, M. J., Crouch, B. G., van Putten, L. M., and van Bekkum, D. W. (1961). Fournal of the National Cancer Institute, 27, 67.

Epstein, R. B., Storb, R., Clift, R. A., and Thomas, E. D. (1969). Cancer Research, 29, 1072.

Fulginiti, V. A., et al. (1968). New England fournal of Medicine, 279, 619.

Keast, D. (1968). Immunology, 15, 237.

Kelly, W. D., et al. (1967). Surgery, 62, 704

Ledney, G. D. (1969). Transplantation, 8, 127

McDermott, W. (1957). Yale fournal of Biology and Medicine, 30, 257.

Mathé, G., et al. (1965). European fournal of Cancer, 1, 75.

Mathé, G., et al. (1967). Scandinavian fournal of Haematology, 4, 193.

Meuwissen, H. J., Gatti, R. A., Terasaki, P. I., Hong, R., and Good, R. A. (1969). New England fournal of Medicine, 281, 691.

Montgomery, J. R., et al. (1969). Abstract: Ninth Interscience Conference on Antimicrobial Agents and Chemotherapy, Washington D.C., October.

Pegg, D. E. (1966). Bone Marrow Transplantation, p. 71. London, LloydLuke.

Rifkind, D., Faris, T. D., and Hill, R. B., jun. (1966). Annals of Internal Medicine, 65, 943.

Rifkind, D., Marchioro, T. L., Waddell, W. R., and Starzl, T. E. (1964). fournal of the American Medical Association, 189, 397.

Solberg, C. O., et al. (1970). Applied Microbiology. In press.

van 'Bekkum, D. W., and de Vries, M. J. (1967). Radiation Chimaeras. London, Logos Press.

van Bekkum, D. W., Dicke, K. A., Balner, H., Hollander, C. F., and van Putten, L. M. (1970). Experimental Hematology, 20, 27.

\title{
Measles Immunoglobulins in Subacute Sclerosing Panencephalitis
}

\author{
J. H. CONNOLLY, MARGARET HAIRE, DIANA S. M. HADDEN
}

British Medical fournal, 1971, 1, 23-25

\begin{abstract}
Summary
Normal responses of measles specific immunoglobulins $M$ and G (IgM and IgG) were defined in 10 children with measles. Abnormal responses of measles IgM and IgG were found in both sera and cerebrospinal fluids from three cases of subacute sclerosing panencephalitis. In two patients the serum titres of measles IgM and IgG were abnormally high. The measles IgM was present during prolonged illnesses in serum and cerebrospinal fluid, which suggested a correlation with the known persistence of measles virus antigen in the brain of the three patients. It was concluded that both measles IgM and IgG may be produced within the central nervous system in subacute sclerosing panencephalitis.
\end{abstract}

\section{Introduction}

The viral aetiology of subacute sclerosing panencephalitis was suggested by the finding of Cowdry type A inclusions (Dawson, 1933) and paramyxovirus-like filaments in brain (Bouteille, Fontaine, Vedrenne, and Delarue, 1965). Measles antibody in high or increasing titre was found in serum and cerebrospinal fluid (C.S.F.) and measles virus antigen was found in the brain of the same patients (Connolly, Allen,

Department of Microbiology, The Queen's University of Belfast, Belfast BT12 6BN

J. H. CONNOLLY, M.D., M.R.C.PATH., Consultant Virologis

MARGARET HAIRE, M.D., Senior Experimental Officer

DIANA S. M. HADDEN, M.B., D.C.H., Research Assistan
Hurwitz, and Millar, 1967; Freeman, Magoffin, Lennette, and Herndon, 1967). Further evidence of the relationship between measles virus and subacute sclerosing panencephalitis was reported at a conference (Sever and Zeman, 1968) and measles virus has now been isolated from cultured brain cells of patients with this disease (Baublis and Payne, 1968; HortaBarbosa, Fuccillo, Sever, and Zeman, 1969).

Measles IgM and IgG were titrated in 10 children with measles and in three previously reported patients with subacute sclerosing panencephalitis to assess the diagnostic value of the immunoglobulin responses in both acute and persistent measles virus infections.

\section{Patients, Materials, and Methods}

The childhood measles group consisted of nine children with uncomplicated measles and one child with measles-associated encephalitis who recovered completely. Serum samples were obtained from all children, and a C.S.F. sample from the child with encephalitis. "Normal" C.S.F. samples were obtained during diagnostic lumbar pneumoencephalography from four patients with epilepsy and one patient with a head injury. The clinical, pathological, epidemiological, and virological data on the three cases of subacute sclerosing panencephalitis have already been reported (Connolly, Allen, Hurwitz, and Millar, 1968).

All specimens were stored at $-20^{\circ} \mathrm{C}$, except the normal C.S.F. samples, which were stored at $-70^{\circ} \mathrm{C}$, and were tested for measles complement-fixing antibody to confirm the diagnosis of measles where necessary. Virus specific $\operatorname{IgM}$ and IgG were detected with sheep antihuman IgM and IgG (Wellcome Reagents Ltd.) by the indirect immunofluorescence technique (Haire and Hadden, 1970). Serum and C.S.F. 